\title{
Immunization of Goats against Inhibin Increased Follicular Development and Ovulation Rate
}

\author{
Kazuaki SASAKI ${ }^{1)}$, Mohamed S. MEDAN ${ }^{2,3)}$, Gen WATANABE ${ }^{3,4)}$, \\ Sayed SHARAWY' ${ }^{2)}$ and Kazuyoshi TAYA ${ }^{3,4}$ \\ ${ }^{1)}$ Central Research Laboratory, Hitachi, Ltd., Tokyo 185-8601, Japan, ${ }^{2)}$ Department of \\ Theriogenology, Faculty of Veterinary Medicine, Suez Canal University, Ismailia, Egypt, \\ ${ }^{3)}$ Laboratory of Veterinary Physiology, Department of Veterinary Medicine, Faculty of \\ Agriculture, Tokyo University of Agriculture and Technology, Tokyo 183-8509 and \\ 4) Department of Basic Veterinary Science, The United Graduate School of Veterinary Sciences, \\ Gifu University, Gifu 501-1193, Japan
}

\begin{abstract}
In the present study, two experiments were conducted to induce superovulation in goats using passive and active immunization against inhibin. In the first experiment, two groups of goats were given an intravenous injection of either $10 \mathrm{ml}$ normal goat serum (control; $\mathrm{n}=6$ ) or inhibin antiserum developed against [Tyro ${ }^{30}$ ]-inhibin $\alpha$ (1-30) (passively immunized; $\mathrm{n}=6$ ) $48 \mathrm{~h}$ before treatment with $\mathrm{PGF}_{2} \alpha$. In the second experiment, two groups of goats were immunized with inhibin vaccine (actively immunized; $n=5$ ) or Freund's adjuvant (control; $n=5$ ) followed by three booster immunizations at 4 week intervals. Blood samples were collected for determination of FSH, LH, estradiol-17 $\beta$, and progesterone. Ultrasonography was used to determine ovarian activity at $\mathrm{PGF}_{2} \alpha$ injection and ovulation rate one week after estrus. In both experiments, there was a significant increase in plasma FSH concentration compared with the controls. However, the pattern of the FSH levels was different between the passively and actively immunized goats. The numbers of follicles in passively and actively immunized goats $(22.4 \pm 2.3$ and $18.6 \pm 2.1$, respectively) were significantly greater than those in the controls $(2.6 \pm 0.4$ and $2.3 \pm 0.4$, respectively). In addition, the ovulation rate was greater in the immunized animals compared with the controls. Therefore, either passive or active immunization against inhibin could be used to induce superovulation in goats.

Key words: Goats, Inhibin, Ovulation rate, Passive and active immunization
\end{abstract}

(J. Reprod. Dev. 52: 543-550, 2006)

nhibin is a heterodimeric glycoprotein hormone that selectively inhibits secretion of follicle stimulating hormone (FSH) from the pituitary gland [1]. A negative relationship between plasma concentrations of FSH and inhibin has been established in several mammalian species [2, 3]. The number of follicles that develop to ovulatory size depends on both the amount of FSH and the

Accepted for publication: May 5, 2006

Published online: June 7, 2006

Correspondence: K. Taya (e-mail: taya@cc.tuat.ac.jp) time of exposure to FSH $[4,5]$. The release of FSH by the pituitary is in turn controlled by synergistic action of two of the major products of ovulatory follicles, inhibin and estradiol $[6,7]$. Previous findings [8-10] that immunoneutralization of endogenous inhibin produced a significant elevation of peripheral FSH offer evidence that inhibin is an important factor in the inhibitory regulation of FSH secretion in domestic animals as well as laboratory animals [11-13]. On the other hand, ultrasonographic observation of the ovary 
correlated with hormonal profiles demonstrated that an increase in plasma FSH preceded emergence of each follicular wave [14-17] and a decrease in FSH was coincident with functional selection of follicles $[15,18]$, suggesting that the fluctuation in peripheral FSH levels is a trigger for growth, selection, and atresia of follicles. Multiple ovulations have been induced successfully by passive immunization against endogenous inhibin in several species, such as rats [1], ewes [19, 20], hamsters [12], cows [21, 22], mares [10], guinea pigs [13], mice [23], and goats [24, 25]. Also, active immunization against inhibin has been used in cows [26-28], goats [29], ewes [30], and mares [31]. Thus, these initial results indicate that immunization of animals against endogenous inhibin to induce superovulation through increased endogenous FSH secretion is an alternative method to the current exogenous gonadotropin protocols.

In most studies, the use of a combination of equine chorionic gonadotrophin (eCG) and human chorionic gonadotropin ( $\mathrm{hCG}$ ) is the most common method for induction of superovulation in goats. However, a disadvantage of these protocols is the long half-life of eCG, which interferes with normal fertilization and embryo development [32-34], and repeated eCG treatments induced anti-eCG antibodies that clearly have negative effects on the reproduction of goats [35]. There is a few previous studies regarding immunization against inhibin and further investigation is needed. Therefore, the aim of the present study was to determine the effect of passive and active immunization against inhibin on FSH secretion, follicular development, and ovulation rate in goats.

\section{Materials and Methods}

\section{Experimental animals and treatments}

The goats (Capra hircus) used in this study were housed under natural day lighting and fed a maintenance diet of $700 \mathrm{~g} /$ animal daily of hay cubes. Estrous cycles were synchronized with 2 injections of $125 \mu \mathrm{g}$ of a synthetic analogue of prostaglandin $\mathrm{F}_{2} \alpha\left(\mathrm{PGF}_{2} \alpha\right)$ (Estrumate, ScheringPlough Animal Health, NJ, USA) 11 days apart. Estrous behavior was checked every $6 \mathrm{~h}$ with an aproned mature buck throughout the experimental period. On day 10 of the estrous cycle (day $0=$ the first day showing estrous behavior), the goats were passively or actively immunized against inhibin. In passively immunized goats, animals were treated with i.v. injection of $10 \mathrm{ml}$ normal goat serum (control; $\mathrm{n}=6$ ) or $10 \mathrm{ml}$ inhibin antiserum raised in ovariectomized goats as described by Araki et al. [36] (passively immunized; $n=6)$. Two days later (0 h), all animals were injected with $125 \mu \mathrm{g} \mathrm{PGF}_{2} \alpha$ to induce estrus and ovulation. Blood samples were collected at 6-h intervals from $24 \mathrm{~h}$ before until $72 \mathrm{~h}$ after treatment with $\mathrm{PGF}_{2} \alpha$. In actively immunized goats, animals were treated with subcutaneous injection of $1 \mathrm{ml}$ inhibin vaccine emulsified in $1 \mathrm{ml}$ Freund's complete adjuvant into 4 different sites followed by 3 booster injections at 4 weeks intervals (actively immunized; $\mathrm{n}=5$ ) or were treated with $\mathrm{s} / \mathrm{c}$ injection of $1 \mathrm{ml}$ saline emulsified in $1 \mathrm{ml}$ Freund's complete adjuvant (control; $n=5$ ). After the 3rd booster immunization, $\mathrm{PGF}_{2} \alpha$ was used to induce estrus and ovulation. Blood samples were collected at 6-h intervals from $24 \mathrm{~h}$ before until $72 \mathrm{~h}$ after $\mathrm{PGF}_{2} \alpha$ injection. Blood samples were collected into heparinized Vacutainer tubes (Terumo Venoject II, Tokyo, Japan), centrifuged at $1700 \mathrm{~g}$ for 15 minutes, and the plasma was separated and stored at $-20 \mathrm{C}$ until assayed for hormones.

\section{Ultrasound scanning and determination of ovarian response}

The number of follicles $\geq 4 \mathrm{~mm}$ in diameter and corpora lutea were determined at the time of $\mathrm{PGF}_{2} \alpha$ injection, and the ovulation rate was determined one week after induction of estrus using a B-mode scanner (ECHOPAL ultrasound scanner, Hitachi Medical Corporation, Tokyo, Japan) equipped with a $7.5 \mathrm{MHz}$ transrectal transducer. The ovulation rate was determined by counting the number of corpora lutea.

\section{Hormone analysis}

Plasma concentrations of FSH and LH were measured by a radioimmunoassay (RIA) system as described by Araki et al. [36] using anti-ovine FSH (AFP-c5288113), NIDDK-FSH-I-1 for radioiodination, and NIDDK-oFSH-RP-1 as a reference standard. Plasma concentrations of $\mathrm{LH}$ were measured by RIA as described by Mori and Kano [37] using anti-ovine LH (YM No.18), NIDDK-oLH-1-3 for radioiodination, and NIDDKoLH-RP-24 as a reference standard. The intra- and interassay coefficients of variation were $9.8 \%$ and $12.6 \%$ for $\mathrm{FSH}$ and $5.9 \%$ and $6.5 \%$ for $\mathrm{LH}$, 

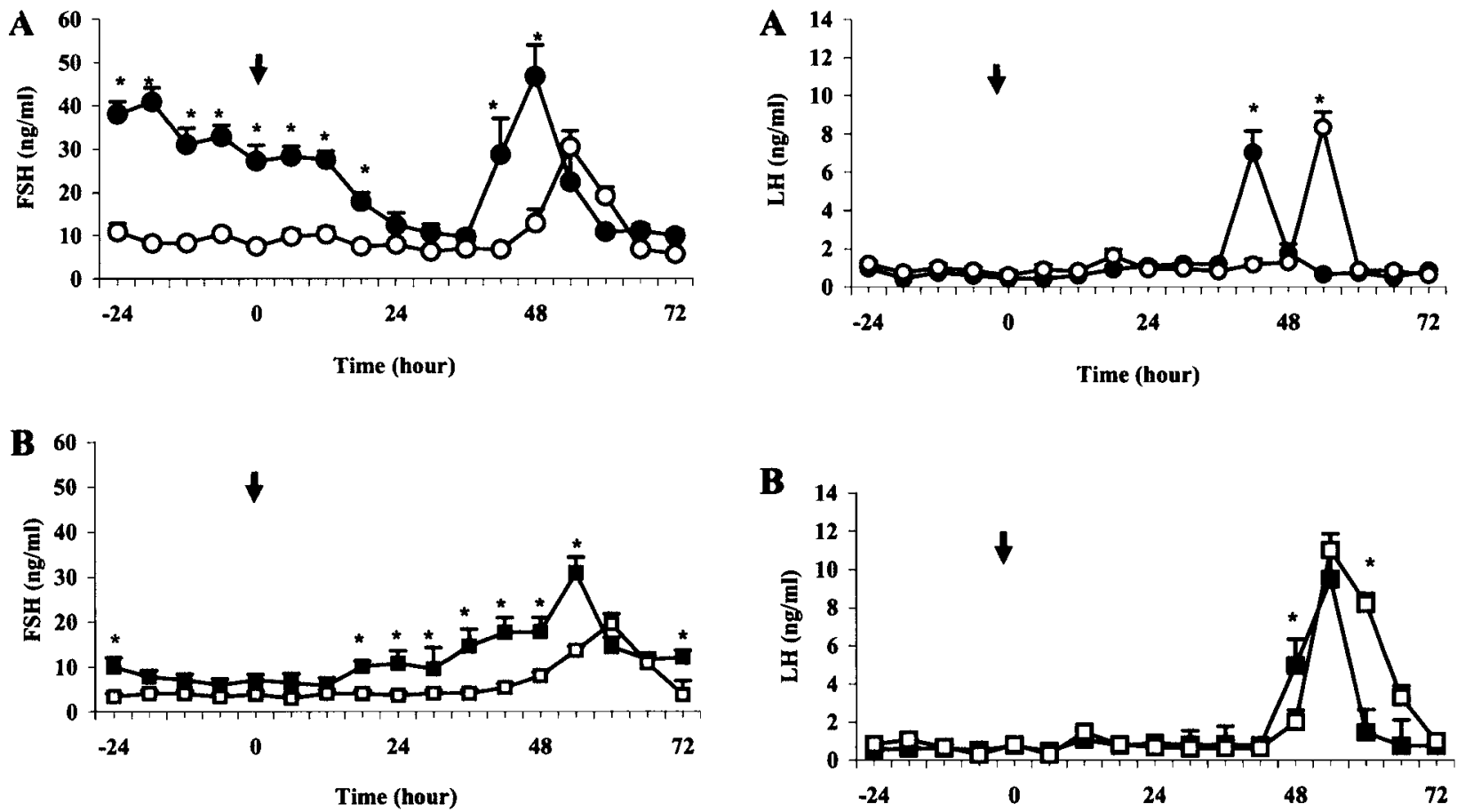

Fig. 1. Changes in plasma concentrations of FSH in goats after treatment with inhibin-AS (-O-) or normal goat serum (- $\left.-^{-}\right)$(A) and after the 3 rd booster immunization against inhibin (- - ) or Freund's adjuvant $\left(-\Gamma^{-}\right)(\mathrm{B})$. The arrows indicate the time of $\mathrm{PGF}_{2} \alpha$ injection. Values are means \pm SEM of six (A) or five (B) animals. ${ }^{*} \mathrm{P}<0.05$ : significance of differences between the immunized and control groups.

respectively. Plasma concentrations of estradiol$17 \beta$ and progesterone were determined by a double antibody RIA system using ${ }^{125}$ I-labeled radioligands as described previously [38]. Antisera against estradiol-17 $\beta$ (GDN 244) and progesterone (GDN 337) were kindly provided by Dr. G. D. Niswender (Animal Production and Biotechnology, Colorado State University, Fort Collins, CO, USA). The intra- and interassay coefficients of variation were $5.8 \%$ and $7.2 \%$ for estradiol- $17 \beta$ and $8.0 \%$ and $8.9 \%$ for progesterone, respectively.

\section{Statistical analysis}

Mean values ( \pm SEM) were calculated and analyzed using 2-way ANOVA. Duncan's multiple-range test was used for detection of significant differences using the SAS computer package [39]. A value of $\mathrm{P}<0.05$ was considered to be statistically significant.

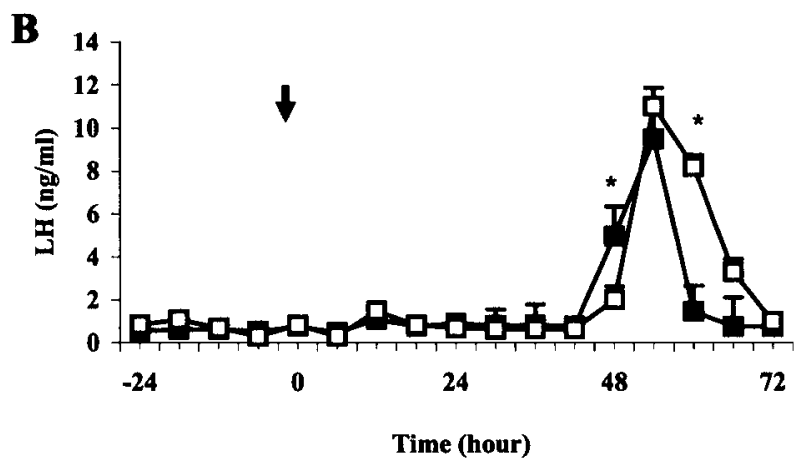

Fig. 2. Changes in plasma concentrations of LH in goats after treatment with inhibin-AS (-O) or normal goat serum $\left(-\bigcirc^{-}\right)(\mathrm{A})$ and after the 3rd booster immunization against inhibin (- - ) or Freund's adjuvant $\left(-\Gamma^{-}\right)(B)$. The arrows indicate the time of $\mathrm{PGF}_{2} \alpha$ injection. Values are means \pm SEM of six (A) or five (B) animals. ${ }^{*} \mathrm{P}<0.05$ : significance of differences between the immunized and control groups.

\section{Results}

\section{Plasma concentrations of FSH and $\mathrm{LH}$}

The plasma concentrations of FSH and LH are shown in Figs. 1 and 2. Treatment of the goats with inhibin antiserum (passively immunized group) or inhibin vaccine (actively immunized group) resulted in a marked increase $(\mathrm{P}<0.05)$ in the plasma concentrations of FSH from the basal levels compared with the controls. In addition, the preovulatory FSH peak in the inhibin-immunized groups was higher than in the control groups. However, the pattern of FSH secretion was different between the passively and actively immunized goats. Plasma concentrations of FSH gradually declined from the time of $\mathrm{PGF}_{2} \alpha$ injection $(0 \mathrm{~h})$ to $36 \mathrm{~h}$ after $\mathrm{PGF}_{2} \alpha$ injection in the passively immunized group, whereas it gradually increased from $12 \mathrm{~h}$ to $54 \mathrm{~h}$ after $\mathrm{PGF}_{2} \alpha$ injection in the 

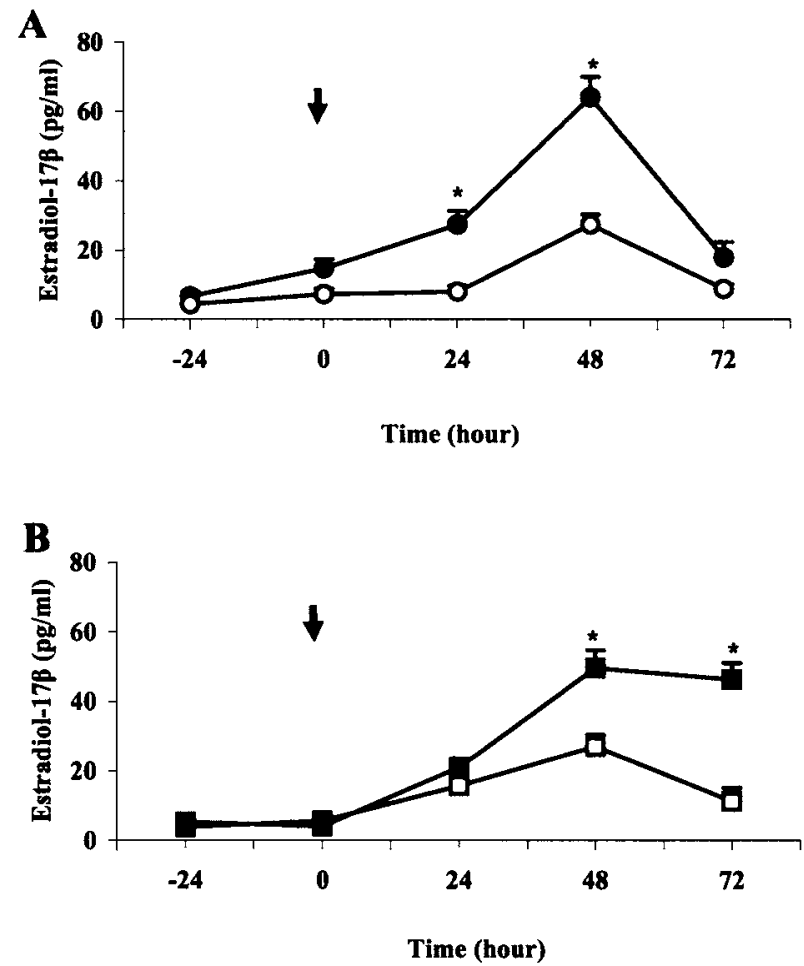

Fig. 3. Changes in plasma concentrations of estradiol-17 $\beta$ in goats after treatment with inhibin-AS (-)-) or normal goat serum (-O-) (A) and after the 3rd booster immunization against inhibin (--) or Freund's adjuvant $\left(-\Gamma^{-}\right)(\mathrm{B})$. The arrows indicate the time of $\mathrm{PGF}_{2} \alpha$ injection. Values are means \pm SEM of six (A) or five (B) animals. ${ }^{*} \mathrm{P}<0.05$ : significance of differences between the immunized and control groups.

actively immunized group. On the other hand, there were no significant changes in the basal levels of LH in all groups (Fig. $2 \mathrm{~A}$ and B). The peak of the LH surge occurred $12 \mathrm{~h}$ earlier in the passively immunized group compared with the control group, although the peak level was not different.

\section{Estradiol-17 $\beta$ and progesterone}

Plasma concentrations of estradiol- $17 \beta$ and progesterone were measured every $24 \mathrm{~h}$ throughout the experiment. In both groups, plasma concentrations of estradiol-17 $\beta$ rose after PG-induced luteolysis and reached a peak value that was significantly $(\mathrm{P}<0.05)$ higher in the immunized groups than in the controls (Fig. $3 \mathrm{~A}$ and $\mathrm{B})$. Thereafter, estradiol-17 $\beta$ declined rapidly in the passively immunized group compared with the control group, whereas the high level remained at $72 \mathrm{~h}$ after $\mathrm{PGF}_{2} \alpha$ injection in the actively
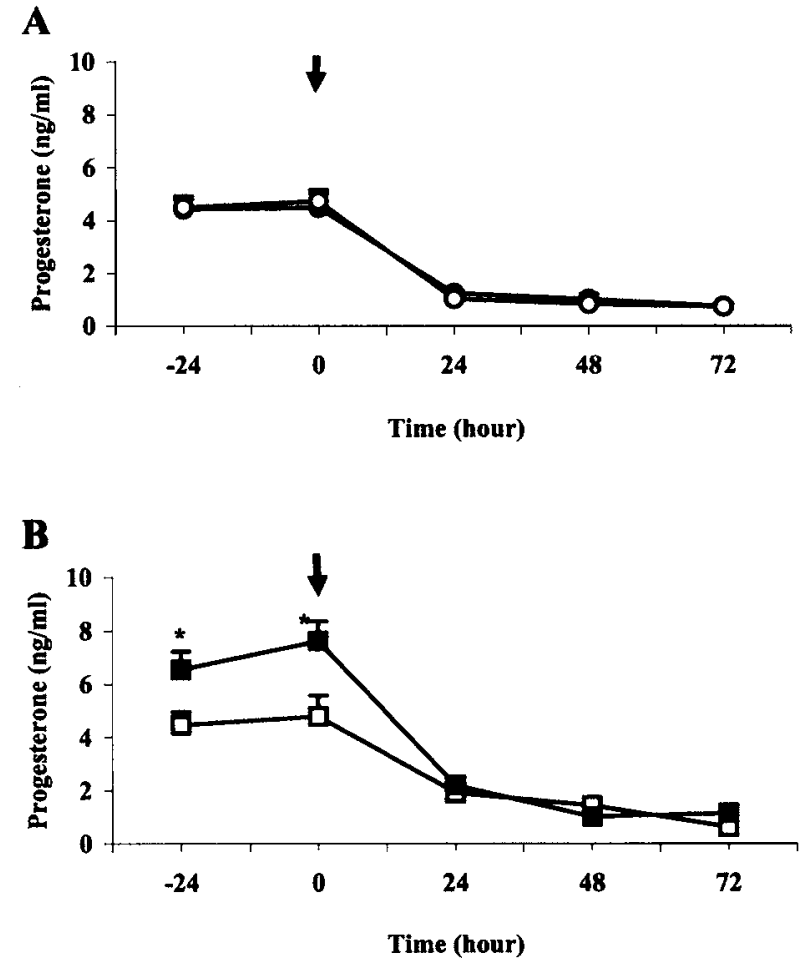

Fig. 4. Changes in plasma concentrations of progesterone in goats after treatment with inhibin-AS (-) or normal goat serum (- - ) (A) and after the 3rd booster immunization against inhibin (- - ) or Freund's adjuvant $\left(-\Gamma^{-}\right)(B)$. The arrows indicate the time of $\mathrm{PGF}_{2} \alpha$ injection. Values are mean \pm SEM of six $(\mathrm{A})$ or five (B) animals. ${ }^{*} \mathrm{P}<0.05$ : significance of differences between the immunized and control groups.

immunized group. On the other hand, plasma concentrations of progesterone suddenly decreased after $\mathrm{PGF}_{2} \alpha$ injection in the passively and actively immunized groups (Fig. 4 A and B). At the time of $\mathrm{PGF}_{2} \alpha$ injection, the progesterone level was significantly $(\mathrm{P}<0.05)$ higher compared with the control value in the actively immunized group, indicating more ovarian activity (higher number of corpora lutea, Table 1).

\section{The effect of immunization against inhibin on ovarian response}

As determined by ultrasound scanning, the number of corpora lutea was significantly higher in the actively immunized group than the other groups (Table 1). Thereafter, there was a significant $(\mathrm{P}<0.01)$ rise in the total number of follicles $(\geq 4 \mathrm{~mm}$ in diameter) in animals immunized against inhibin either passively or actively compared with the 
Table 1. Effect of passive and active immunization against inhibin on ovarian response in goats

\begin{tabular}{|c|c|c|c|}
\hline \multirow[t]{2}{*}{ Group } & \multicolumn{3}{|c|}{ Ovarian response } \\
\hline & Number of corpora lutea ${ }^{(a)}$ & $\begin{array}{l}\text { Number of follicles } \\
\geq 4 \mathrm{~mm} \text { in diameter }{ }^{(a)}\end{array}$ & Ovulation rate ${ }^{(b)}$ \\
\hline $\begin{array}{l}\text { Goats passively immunized } \\
\text { against inhibin }(n=6)\end{array}$ & $1.8 \pm 0.4$ & $22.4 \pm 2.3^{* *}$ & $9.4 \pm 1.4^{* *}$ \\
\hline $\begin{array}{l}\text { Goats injected with normal } \\
\text { goat serum }(n=6)\end{array}$ & $2.0 \pm 0.4$ & $2.6 \pm 0.4$ & $2.2 \pm 0.6$ \\
\hline $\begin{array}{l}\text { Goats actively immunized } \\
\text { against inhibin }(n=5)\end{array}$ & $6.6 \pm 0.8^{* *}$ & $18.6 \pm 2.1^{* *}$ & $8.6 \pm 1.3^{* *}$ \\
\hline $\begin{array}{l}\text { Goats injected with Freund's } \\
\text { adjuvant }(n=5)\end{array}$ & $1.8 \pm 0.4$ & $2.3 \pm 0.4$ & $1.8 \pm 0.3$ \\
\hline
\end{tabular}

**: $\mathrm{P}<0.01$, significantly different compared with the other values in the same column.

(a) By using ultrasound scanning at the time of $\mathrm{PGF}_{2} \alpha$ injection.

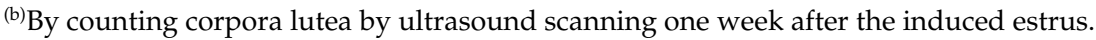

control values. In the group immunized with inhibin antiserum, the number of follicles was 22.4 \pm 2.3 , while it was $2.6 \pm 0.4$ in the control group. In addition, the number of follicles was $18.6 \pm 2.1$ in goats actively immunized against inhibin compared with the control group $(2.3 \pm 0.4)$. The ovulation rate was $9.4 \pm 1.4$ and $8.6 \pm 1.3$, respectively, in the passively and actively immunized goats compared with the control groups (2.2 \pm 0.6 and $1.8 \pm 0.3)$.

\section{Discussion}

The present study clearly demonstrated that immunoneutralization of endogenous inhibin in cyclic goats either passively or actively caused an increase in plasma concentrations of FSH which, in turn, led to stimulation of ovarian follicular development and an increased ovulation rate. The magnitude and quantitative nature of the FSH secretory profiles induced by passive immunization support an endocrine role for inhibin in regulating FSH secretion in goats. Thus, inhibin, through negative feedback regulation of FSH secretion, appears to be an important factor in regulation of follicular development in the goat. In previous studies, a significant increase in plasma concentrations of FSH has been shown by passive immunization against inhibin during the estrous cycle in cows [9, 21, 22], sheep [19, 40-42], rats [43], mice [44], hamsters [12, 45], and guinea pigs [13], indicating the important role of inhibin in regulating FSH secretion during the estrous cycle in these species. The rise in FSH concentration seen following immunization resulted in marked stimulation of follicular growth and improved ovarian response. The observation that the rise in plasma FSH preceded the emergence of new follicles leads to the conclusion that hypersecretion of FSH stimulates multiple growth of follicles. This action, timed to coincide with $\mathrm{PGF}_{2} \alpha$ injection in the present study, enlarged the pool of recruitable follicles, and this gave rise to a greater ovulation rate in the immunized goats. Previous results obtained from active immunization [47] or repeated injections of inhibin antiserum [8, 48] have indicated a possibility that ovarian response to inhibin immunization is not only mediated by the rise in circulating FSH levels but is also mediated by the direct effect of immunization on follicular growth probably through local effects of inhibins in the ovary. Regarding LH levels, there was no marked change in the basal LH concentrations between the immunized and control goats. Plasma concentrations of estradiol-17 $\beta$ rose after $\mathrm{PGF}_{2} \alpha$ injection in all goats. The peak levels of the plasma concentrations of estradiol-17 $\beta$ in the immunized groups were significantly higher than in the controls. This was similar to previous results recorded in goats [49]. The increase in the plasma concentrations of estradiol- $17 \beta$ was probably due to increased numbers of estrogenic follicles destined to ovulate. The high level of plasma estradiol-17 $\beta$ induced the LH surge $12 \mathrm{~h}$ earlier in the passively immunized group, and this is similar to the results reported previously by Campbell and Scaramuzzi [50]. In addition, estradiol-17 $\beta$ remained relatively 
high in the actively immunized group, suggesting that large follicles capable of secreting estradiol- $17 \beta$ still remained in the ovaries of the actively immunized group. This probably depends on circulating levels of FSH. At the time of $\mathrm{PGF}_{2} \alpha$ injection, the progesterone level was significantly higher in the actively immunized group than in the controls. This might reflect increased numbers of corpora lutea.

It is well known that repeated use of eCG to induce superovulation in goats results in diverse effects because of the formation of anti-eCG antibodies [35]. Therefore, use of passive or active immunization against inhibin is a suitable, simple, and practical alternative to $\mathrm{eCG}$ for induction of superovulation in goats. Moreover, active immunization against inhibin improves superovulatory response to exogenous FSH in cattle [27]. In the present study, the ovulation rate was not comparable to the follicular population. Therefore, further studies are needed to improve ovulation rate in inhibin-immunized animals.

In conclusion, the present study demonstrated that inhibin is an important factor as a regulator of FSH secretion in goats. The present results also demonstrated that passive and active immunization against inhibin induced a marked increase in FSH, ovarian follicular population, and ovulation rate. Therefore, neutralization of inhibin bioactivity through passive or active immunization is a practical and potential method for inducing follicular development and increasing ovulation rate in goats.

\section{Acknowledgments}

We are grateful to Dr. A. F. Parlow and the National Institute of Diabetes and Digestive and Kidney Diseases, Torrance, CA, USA, for providing RIA materials for ovine FSH and LH; Dr. Y. Mori, University of Tokyo, for providing antisera to ovine LH (YM\#18); and Dr. G. D. Niswender (Animal Reproduction and Biotechnology Laboratory, Colorado State University, Fort Collins, CO, USA) for providing antisera to estradiol-17 $\beta$ (GDN 244) and progesterone (GDN 337). This work was supported in part by a Grant-in-Aid for Scientific Research (The $21^{\text {st }}$ Century Center of Excellence Program, E-1) from the Ministry of Education, Culture, Sports, Science and Technology of Japan and a Grant-in-Aid for Scientific Research (No.18310044) from the Japan Society for the Promotion of Science.

\section{References}

1. Burger HG. Inhibin: definition and nomenclature, including related substances. J Endocrinol 1988; 117: 159-160.

2. Taya K. Role of inhibin in regulation of FSH secretion and folliculogenesis in mammals. Curr Trends Exp Endocrinol 1993; 1: 97-116.

3. Taya K, Watanabe G. Inhibin as a key hormone in determining species-specific ovulation rates in mammal. In: Known HB, Joss JMP, Ishii S (eds.) Recent Progress in Molecular and Comparative Endocrinology, Hormone Research Center, Chonman National University, Kwangju; 1999: 134143.

4. Picton HM, Tsonis CG, McNeilly AS. FSH causes a time-dependent stimulation of preovulatory follicle growth in the absence of pulsatile LH secretion in GnRH agonist treated ewes. J Endocrinol 1990; 126: 297-307.

5. McNeilly AS, Crow W, Campbell BK. Effect of follicular fluid and inhibin immunoneutralization on FSH-induced preovulatory follicle growth in the ewe. J Endocrinol 1991; 131: 401-409.
6. Martin GB, Price CA, Thiery JC, Webb R. Interactions between inhibin, estradiol and progesterone in the control of gonadotrophin secretion in the ewe. J Reprod Fertil 1988; 82: 319-328.

7. Mann GE, Campbell BK, McNeilly AS, Baird DT. The role of inhibin and estradiol in the control of FSH secretion in the sheep. J Endocrinol 1992; 133: 381-391.

8. Campbell BK, Scaramuzzi RJ. Effect of acute immunoneutralization of inhibin in ewes during the late luteal phase of the estrous cycle on ovarian hormone secretion and follicular development during the subsequent follicular phase. J Reprod Fertil 1995; 104: 337-345.

9. Kaneko H, Nakanishi Y, Akagi S, Taya K, Watanabe G, Sasamoto S, Hasegawa Y. Immunoneutralization of inhibin and estradiol during the follicular phase of the oestrus cycle in cows. Biol Reprod 1995; 53: 931-939.

10. Nambo $\mathbf{~ , ~ K a n e k o ~} \mathbf{H}$, Nagat $\mathbf{S}$, Oikawa $\mathbf{M}$, Yoshihara T, Nagamine N, Watanabe G, Taya K. Effect of passive immunization against inhibin on 
FSH secretion, folliculogenesis and ovulation rate during the follicular phase of estrous cycle in mares. Theriogenology 1998; 50: 545-557.

11. Rivier C, Vale W. Immunization of endogenous inhibin modifies hormone secretion and ovulation rate in the rat. Endocrinology 1989; 125: 152-157.

12. Kishi H, Okada T, Otsuka M, Watanabe G, Taya K, Sasamoto S. Induction of superovulation by immunoneutralization of endogenous inhibin through the increase in the secretion of follicle stimulating hormone in the cyclic golden hamster. $J$ Endocrinol 1996; 151: 65-75.

13. Shi F, Mochida K, Suzuki O, Mateuda J, Ogura A, Ozawa M, Watanabe G, Suzuki A, Taya K. Ovarian localization of immunoglobulin $\mathrm{G}$ and inhibin $\alpha-$ subunit in guinea pigs after passive immunization against the inhibin $\alpha$ subunit. J Reprod Dev 2000; 46: 293-299.

14. Adams GP, Matteri RL, Kastelic JP, Ko JCH, Ginther OJ. Association between surges of folliclestimulating hormone and the emergence of follicular waves in heifers. J Reprod Fertil 1992; 4: 177-188.

15. Sunderland SJ, Crowe MA, Boland MP, Roche JF, Ireland JJ. Selection, dominance and atresia of follicles during the estrous cycle of heifers. J Reprod Fertil 1994; 101: 547-555.

16. Kaneko H, Kishi H, Watanabe G, Taya K, Sasamoto S, Hasegawa Y. Changes in plasma concentrations of immunoreactive inhibin, estradiol and FSH associated with follicular waves during the oestrus cycle of the cow. J Reprod Dev 1995; 41: 311320.

17. Evans ACO, Komar CM, Wandji SA, Fortune JE. Changes in androgen secretion and luteinizing hormone pulse amplitude are associated with the recruitment and growth of ovarian follicles during the luteal phase of the bovine estrous cycle. Biol Reprod 1997; 57: 394-401.

18. Kulick LJ, Wiltbank MC, Ginther OJ. Follicular and hormonal dynamics during the first follicular wave in heifers. Theriogenology 1999; 52: 913-921.

19. Wheaton JE, Carlson KM, Kusina NT. Active and passive immunoneutralization of inhibin increases follicle-stimulating hormone levels and ovulation rate in ewes. Biol Reprod 1992; 47: 361-367.

20. Wheaton JE, Thomas DL, Kusina T, Gottfrendson RG, Meyer RL. Effects of passive immunization against inhibin-peptide on secretion of folliclestimulating hormone and ovulation rate in ewes carrying the Booroola fecundity gene. Biol Reprod 1996; 55: 1351-1355.

21. Akagi S, Kaneko H, Nakanishi Y, Takedomi T, Watanabe G, Taya K. Ovarian response and FSH profile in cows following injection of various doses of inhibin antiserum. J Vet Med Sci 1997; 59: 11291135.
22. Takedomi T, Kaneko H, Aoyagi Y, Konishi K, Kishi H, Watanabe G, Taya K. Effects of passive immunization against inhibin on ovulation rate and embryo recovery in Holstein heifers. Theriogenology 1997; 47: 1507-1518.

23. Wang H, Herath CB, Xia G, Watanabe G, Taya K. Superovulation, fertilization and in vitro embryo development in mice after administration of an inhibin-neutralizing antiserum. Reproduction 2001; 122: 809-816.

24. Medan MS, Watanabe G, Sasaki K, Nagura Y, Sakaime H, Fujita M, Sharawy S, Taya K. Effects of passive immunization of goats against inhibin on follicular development, hormone profile and ovulation rate. Reproduction 2003; 125: 751-757.

25. Medan MS, Watanabe G, Nagura Y, Sakaime H, Fujita M, Sharawy S, Taya K. Passive immunoneutralization of endogenous inhibin increases ovulation rate in miniature Shiba goats. $J$ Reprod Dev 2004; 50: 705-710.

26. Glencross RG, Bleach EC, Wood SC, Knight PG. Active immunization of heifers against inhibin: effects on plasma concentrations of gonadotrophins, steroids and ovarian follicular dynamics during prostaglandin-synchronized cycles. J Reprod Fertil 1994; 100: 599-605.

27. Takedomi T, Kishi H, Medan MS, Aoyagi $Y$, Konishi M, Itoh T, Yazawa S, Watanabe G, Taya K. Active immunization against inhibin improves superovulatory response to exogenous $\mathrm{FSH}$ in cattle. J Reprod Dev 2005; 51: 341-346.

28. Medan MS, Akagi S, Kaneko H, Watanabe G, Tsonis CG, Taya K. Effects of re-immunization of heifers against inhibin on hormonal profiles and ovulation rate. Reproduction 2004; 128: 475-482.

29. Medan MS, Watanabe G, Sasaki K, Nagura Y, Sakaime H, Fujita M, Sharawy S, Taya K. Ovarian and hormonal response of female goats to active immunization against inhibin. J Endocrinol 2003; 177: 287-294.

30. O'Shea T, Bindon BM, Forage RG, Findlay JK, Tsonis CG. Active immunization of Merino ewe lambs with recombinant bovine alpha inhibin advances puberty and increases ovulation rate. Reprod Fertil Dev 1993; 5: 173-180.

31. Derar RI, Maeda Y, Hoque SM, Osawa T, Watanabe G, Taya K, Miyake Y. Effect of active immunization of pony mares against recombinant porcine inhibin alpha subunit on ovarian follicular development and plasma steroids and gonadotropins. J Vet Med Sci 2004; 66: 31-35.

32. McIntosh JE, Moore RM, Allen WR. Pregnant mare serum gonadotrophin: rate of clearance from circulation of sheep. J Reprod Fertil 1975; 44: 95-100.

33. Armstrong DT, Pfitzner AP, Warnes GM, Seamark RF. Superovulation treatments and embryo transfer in Angora goats. J Reprod Fertil 1983; 67: 403-410. 
34. Ertzeid G, Storeng R, Lyberg T. Treatment with gonadotropins impaired implantation and fetal development in mice. J Assist Reprod Genet 1993; 10: 286-291.

35. Roy F, Maurel M, Combes B, Vaiman D, Cribiu E, Lantier I, Pobel T, Deletang F, Combarnous Y, Guillou F. The negative effect of repeated equine chorionic gonadotropin treatment on subsequent fertility in Alpine goats is due to a humoral immune response involving the major histocompatibility complex. Biol Reprod 1999; 60: 805-813.

36. Araki K, Arai K, Watanabe G, Taya K. Involvement of inhibin in the regulation of follicle-stimulating hormone secretion in the young adult male shiba goat. J Androl 2000; 21: 558-565.

37. Mori Y, Kano Y. Changes in plasma concentrations of $\mathrm{LH}$, progesterone and estradiol in relation to the occurrence of luteolysis, estrus and time of ovulation in shiba goats (Capra hircus). J Reprod Fertil 1984; 72: 223-230.

38. Taya K, Watanabe G, Sasamoto S. Radioimmunoassay for progesterone, testosterone and estradiol17 $\beta$ using ${ }^{125}$ I-iodohistamine radiolligands. Jpn J Anim Reprod 1985; 31: 186-197.

39. SAS. Statistics, version 6.11, Cary, NC: SAS Institute Inc. 1987.

40. Mann, GE, Campbell BK, McNeilly AS, Baird DT. Follicular development and ovarian hormone secretion following passive immunization of ewes against inhibin or estradiol. J Endocrinol 1993; 136: 225-233.

41. O'Shea T, Hillard MA, Anderson ST, Bindon BM, Findlay JK, Tsonis CG, Wilkins JF. Inhibin immunization for increasing ovulation rate and superovulation. Theriogenology 1994; 41: 3-17.

42. Mann GE, Campbell BK, McNeilly AS, Baird DT. Passively immunizing ewes against inhibin during the luteal phase of the estrous cycle raises the plasma concentration of FSH. J Endocrinol 1989; 123: 383-391.

43. Arai K, Watanabe G, Taya K, Sasamoto S. Roles of inhibin and estradiol in the regulation of folliclestimulating hormone and luteinizing hormone secretion during the estrous cycle of the rat. Biol Reprod 1996; 55: 127-133.

44. Medan MS, Wang H, Watanabe G, Suzuki AK, Taya K. Immunization against endogenous inhibin increases normal oocyte/embryo production in adult mice. Endocrine 2004; 24: 115-119.

45. Kishi H, Okada T, Kawazu S, Otsuka M, Taya K, Watanabe G, Sasamoto S. Effects of passive immunization against oestradiol-17beta and inhibin on the secretion of gonadotrophin in the cyclic golden hamster (Mesocricetus auratus). Reprod Fertil Dev 1997; 9: 447-453.

46. Medan MS, Watanabe G, Sasaki K, Sharawy S, Groome NP, Taya K. Ovarian dynamics and their associations with peripheral concentrations of gonadotropins, ovarian steroids, and inhibin during the estrous cycle in goats. Biol Reprod 2003; 69: 57-63.

47. Bleach ECL, Muttukrishna S, Cunningham FJ, Knight PG, Glencross RG. Effect of inhibin immunization using different synthetic peptide fragments of the bovine $\alpha c$-subunit on plasma antiinhibin titre, plasma FSH concentrations and the incidence of multiple ovulation in heifers. Anim Reprod Sci 1996; 41: 1-12.

48. Campbell BK, Gordon BM, Tsonis CG, Scaramuzzi RJ. The effect of acute immunoneutralization of inhibin in ewes during the early luteal phase of estrous cycle on ovarian hormone secretion and follicular development. J Endocrinol 1995; 145: 479-490.

49. Hennies M, Voglmayr JK, Dietrich E, Stollmann M, Moeller R, Holtz W. Hormonal response of female goats to active immunization against a recombinant human inhibin $\alpha$-subunit, and establishment of an Enzyme-linked immunosorbent assay for caprine follicle-stimulating hormone. Reprod Domest Anim 2001; 36: 65-71.

50. Campbell BK, Scaramuzzi RJ. Effect of acute immunoneutralization of inhibin in ewes during the late luteal phase of the estrous cycle on ovarian hormone secretion and follicular development during the subsequent follicular phase. I Reprod Fertil 1995; 104: 337-345. 